УДК $372.2(71)$

DOI:

Наталія Мукан, доктор педагогічних наук, професор, завідувач кафедри іноземних мов Ірина Миськів, кандидат педагогічних наук, дочент кафедри іноземних мов Марія Запотічна, аспірант, Національний університет “Львівська політехніка"

\title{
АСИМІЛЯЦІЯ В ОСВІТІ КОРІННИХ НАРОДІВ КАНАДИ
}

У статті розглянуто специфіку асиміляційних процесів, притаманних розвитку освіти корінних народів Канади у 18 - 19 століттях. Автори представляють результати аналізу науково-педагогічноі літератури, щзо висвітлює окремі аспекти проблеми дослідження. Вони характеризують особливості функиіонування шкіл-інтернатів, якими опікувалися релігійні громади, висвітлюють негативні аспекти європеїзачії корінних народів, поєднання навчання в аудиторії та формування і розвитку практичних умінь i навичок учнів на основі застосування єврочентристського підходу. Автори формулюють висновки та перспективи подальших досліджень.

Ключові слова: асиміляція; освіта корінних народів; Канада; школа-інтернат.

Лim. 7.

Nataliya Mukan, Doctor of Sciences (Pedagogy), Professor, Head of the Foreign Languages Department Iryna Myskiv, Ph. D. (Pedagogy), Associate Professor, Assistant Professor of the Foreign Languages Department Mariya Zapotichna, Postgraduate Student, Lviv Polytechnic National University

\section{THE ASSIMILATION IN THE EDUCATION OF INDIGENOUS PEOPLES OF CANADA}

According to the systemic approach, the study of education of Canadian indigenous people justifies the necessity to analyse the specificity of different periods in its development. The purpose of the article is defined as research and characteristic of the assimilation processes in the development of Canadian indigenous people's education in the 18th-19th centuries. Therefore, the authors specify the assimilation processes in the development of the indigenous people's education in Canada during the 18th-19th centuries. They present the results of the analysis of scientific and pedagogical literature, which highlights the distinct aspects of the problem under research. The historical and pedagogical analysis shows that European style of education and learning was introduced by colonial governments on the territories of modern Canada. These education innovations were supported by Catholic Church and missionary teachers, who gave the indigenous children manual, Christian and vocational instructions. The education for indigenous children was provided in the residential schools, which aim was to "civilise"the indigenous people. This policy was unsuccessful, because it didn't take into account the indigenous people's traditional ways of life. The authors analyse the historical documents (The Davin Report, Programme of Studies for Indian Schools), which regulated the organization of academic process in such educational establishments as well as characterize the content, the forms and methods of learning. The authors make conclusions on the negative influence of the European-style education in the history of the Canadian indigenous people's education; formulate the prospects for the future research of the problem of indigenous people' educational development in Canada.

Keywords: assimilation; an education of indigenous people; Canada; a residential school.

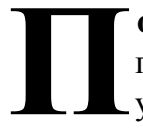
остановка проблеми. Процеси глобалізації, що набули масштабності упродовж останніх десятиліть, сприяли активному розвитку міжнародної торгівлі, підвищенню ролі інтелектуального капіталу, активізації геополітичних процесів, зростанню глобальної економічної інтеграції та відкритому доступу до наявних світових ресурсів, позитивно вплинули і на міжнародний освітній простір. Проте, такі тенденції супроводжуються й негативними явищами, серед яких особливо відчутною $\epsilon$ поступова втрата культурної самобутності народів, що проживають в країнахучасницях. Розуміючи культурну самобутність як національний скарб, який може внести істотний внесок у розвиток будь-якої країни, науковці звертають увагу на необхідність збереження культурної ідентичності народу, зміцнення його національної самосвідомості. Особливе місце відводиться збереженню культурних надбань корінних народів різних країн світу, оскільки їх мова, культура, традиції та звичаї поступово зникають.

Аналіз основних досліджень і публікацій. Проблема розвитку освіти корінних жителів народів світу $є$ предметом наукового пошуку дослідників, серед яких освіту корінних жителів Австралії студіювали Л. Голуб, А. Джуринський, 
Ф. Таунсенд (P. Townsend), С. Осборн (S. Osborne) CША - В. Джейнс (V. Janes), П. Бреді (P. Brady), П. Стюарт (P. Stuart), Р. Уеллс (R.Wells), Дж. Елдер (J. Elder); Нової Зеландії-К. Солніє (К. Saulnier), Г. Рахам (H.Raham), Норвегії (Д. Корсон (D. Corson), C. Квернмо (S. Kvernmo); країн Латинської Америки - Л. Лопес (L. Lopez), I. Сікра (I. Sichra), Р. Кортіна (R. Cortina). Проблеми корінних народів в Україні досліджували А. Сеїтмуратова, М. Хайруддінов, I. Орєхова, I. Лопушинський.

Окремі аспекти освіти корінних жителів Канади розглядались у працях Н. Жорняк, О. Козачук, M. Баттіст (M. Battiste), Дж. Бармена (J. Barman), Дж. Фрізена (J. Friesen), К. Хейг-Брауна (C. HaigBrown), В. Кіркнес(V.Kirkness), Г. Лікерса(H.Lickers), Дж. МакФерсона (J. MacPherson), М. Мендельсона (M. Mendelson), Дж. Міллоя (J. Milloy), Дж. Уайта (J. White). Проте, розвиток освіти корінних народів Канади характеризується наявністю різних періодів, які своєю чергою відзначаються як позитивними, так і негативними аспектами.

Вважаємо за необхідне, дослідити асиміляційні процеси в освіті корінних народів Канади, що і формує мету нашого дослідження. Для досягнення визначеної мети нами сформульовано такі завдання: виконати аналіз науково-педагогічної літератури, що висвітлює різні аспекти розвитку освіти корінних народів Канади; виконати аналіз асиміляційних процесів, що характерні для освіти корінних народів Канади у XIX столітті.

Виклад основного матеріалу дослідження. Як свідчать результати, отримані в історикопедагогічних дослідженнях, політика освітньої асиміляції притаманна багатьом країнам. Така практика не оминула й Канаду з приходом європейців на ii території. Тут 1620 по 1948 рр. характеризуються асиміляційними процесами. 3 метою підвищення рівня освіченості корінних народів Канади, європейці застосували досвід створення шкіл пансіонного типу. Школипансіони, в яких проживали і навчались діти, були широко розповсюджені у тогочасній Франції, Англії, США тощо.

На території Канади функціонували два види шкіл-інтернатів. Перші з них - це школи раннього періоду асиміляції, що тривав приблизно до початку 80-х pp. XIX ст. Такі школи відкривали на території резервацій чи неподалік за їі межами. Вони були невеликі за розмірами. Тут корінних жителів навчали читанню, письму та арифметики, а також особливу увагу приділяли навчанню ведення сільського господарства та фермерської діяльності. Спочатку в таких школах навчали усіх, як дорослих, так і дітей, однак до кінця 40-х рр.
XIX ст. акценти перемістились лише на навчання дітей. Ці школи відкривались за ініціативи уряду i дуже часто їх функціонування підтримувалось певними релігійними конфесіями. Відомо, що у 1848 р. і 1851 р. за сприяння генерала губернатора Канади Лорда Елджіна (Lord Elgin) на сході країни було відкрито дві школи для навчання корінного населення: Алнвікська школа (Alnwick School) у м. Алдервіль (Alderville) та Школа Елджіна (Mount Elgin School) у м. Мюнсей (MunceyTown) [7]. Федеральний уряд Канади щороку виділяв кошти на освіту, проживання та одяг дітей. А методистська церква відповідала за щоденне функціонування школи: забезпечувала вчителів, наглядачів школи та необхідне обладнання для навчального процесу [6].

Однак діяльність таких шкіл не приносила очікуваних результатів. Батьки неохоче записували своїх дітей у школи, а діти, своєю чергою, часто втікали додому і не виявляли бажання повертатись до школи. Крім цього, випускники перших шкіл-інтернатів не виявляли бажання залишатись жити поза межами резервацій і після завершення навчання повертались у свої спільноти, що для тодішнього керівництва свідчило про неефективність політики цивілізації корінних народів. Та найосновнішою проблемою було те, що, повертаючись у свої поселення, випускники шкіл не передавали освоєні знання своєму народові.

Урядовці почали шукати шляхи заохочення корінних жителів до фермерства та сільського господарства та віддаляти їх від представників спільноти, яка, на думку політиків, здійснювала регресивний вплив. У зв'язку з цим, у 1857 р. прийнято Акт про підтримку поступової цивілізації індіанських племен (англ. Act to Encourage Gradual Civilization of Indian Tribes in the Province), згідно з яким кожному індіанцюмужчині, який успішно опанував програму загальноосвітньої школи, не мав боргових зобов'язань і був доброчесним громадянином, виділялось 50 акрів землі, яка повністю переходила у його приватну власність. Такий індіанець (англ. enfranchised Indian) отримував усі громадянські права і ставав повноправним членом колоніального суспільства. Однак, як свідчать історико-педагогічні джерела, і така політика не приносила очікуваних результатів. Концепція приватної власності, осілої фермерської діяльності та ведення сільського господарства була чужою для корінних жителів континенту, які упродовж століть володіли спільною власністю і не розуміли принципів поділу землі й особистого володіння іiі природними ресурсами. Особливо негативно ця 
політика сприймалась лідерами перших націй, які неодноразово висловлювали активну громадськополітичну позицію щодо підтримки традиційного способу життя своїх народів. Як результат, індіанське самоврядування почало розглядатись як основна перешкода на шляху до цивілізації корінного населення. Однією із особливостей розвитку системи освіти корінного населення Канади $є$ те, що не зважаючи на високий рівень децентралізації в системі загальної шкільної освіти провінцій та територій Канади, система освіти корінного населення розвивалась централізовано.

У 1867 р. проголошено утворення нової держави - Канади, федеральний уряд офіційно закріпив за собою повноваження щодо управління законодавчою діяльністю корінних жителів, а політика асиміляції стала офіційною політикою федерального уряду країни, очолюваного першим прем'єр-міністром Канади Дж. МакДональдом (J. McDonald). Федеральний уряд новоутвореної конфедерації продовжував політику попередників щодо корінного населення країни - укладання 3 окремими корінними народами угод, відповідно до яких корінне населення відмовлялось від претензії на землю, залишаючи за собою право лише на окремі території - резервації, а взамін отримувало грошові виплати, фінансові допомоги від федерального уряду, зобов'язання федерального уряду забезпечувати їх освітніми послугами тощо [4]. При федеральному уряді Канади створено спеціальний орган Департамент у справах індіанців (англ. Department of Indian Affairs), який отримав широкі повноваження контролювати соціальний, політичний, культурний, економічний аспекти життя корінного населення, в тому числі отримав повний контроль над їхньою освітньою діяльністю [6].

Одним iз найважливіших історикопедагогічних документів, що визначив подальший напрямок розвитку освіти корінного населення Канади після утворення конфедерації був документ Н. Дейвіна (N. Davin) - високопосадовця, уповноваженого федеральним урядом дослідити діяльність закладів освіти для корінного населення в США, і розробити рекомендації для втілення їх у систему освіти корінного населення Канади. У 1879 р. опубліковано Доповідь Н. Дейвіна (англ. The Davin Report), яка окреслила освітню політику федерального уряду на найближчі десятиліття. Автор запропонував перейняти метод фінансування шкіл для корінних жителів, згідно 3 яким уряд виділяв певну суму грошей на кожного учня, а діяльністю шкіл займались церкви. Основною рекомендацією Н. Дейвіна було підписання контракту федерального уряду iз представниками релігійних конфесій, що володіють школами. Відповідно до кількості дітей у школі уряд повинен виділяти певну суму із федерального бюджету, а церковні представники повинні займатись утриманням та матеріальним оснащенням шкіл, навчанням дітей, забезпеченням їх їжею та одягом, а також найманням вчителів, директорів шкіл та їхніх заступників. Н. Дейвін пропонував відкрити чотири школи на заході країни, які б контролювались представниками чотирьох різних релігійних конфесій: протестантами, методистами, римо-католиками та пресбітерійцями [1]

$380-x$ pp. ХІХ ст. відриваються школиінтернати, а саме - індустріальні школи, що розміщувались в урбанізованих центрах і були набагато більші за розмірами від шкіл-інтернатів раннього періоду асиміляції. Індустріальна школа стає основним механізмом політики “агресивної асиміляціі” , що починає активно розгортатись у наступні десятиліття [1].

Політика агресивної асиміляції передбачала повну ізоляцію дітей від їхніх рідних і близьких та звичного їм культурного середовища. “Доросле населення розглядалось як перешкода на шляху до цивілізації. ... Вони навчали своїх дітей. Їхні діти у звичному для них середовищі навчались від них і від інших дорослих жителів спільноти...” [6;26]. “Дитина, яка трохи щось вивчить, відразу все забуває, тому що їі звички формуються вдома, а успадкований від батьків протест проти тривалої праці неможливо подолати", зауважував Н. Дейвін у своїй доповіді $[2 ; 30]$. Відвідування дітей батьками було обмеженим, а до настирливих батьків залучали правоохоронні органи. Дослідження історико-педагогічних джерел розвитку освіти цього періоду свідчить, що у деяких школах дітей не відпускали додому навіть на період літніх канікул. Закон про обов'язкові двомісячні літні канікули у школах-інтернатах для корінного наслення був ухвалений федеральним урядом Канади лише у 1920 р. [6].

На зразок тогочасних європейських шкіл, у школах-інтернатах існував поділ на класи залежно від віку і статі, тому найчастіше діти, відірвані від батьків, навіть не мали змоги спілкуватись із рідними братами і сестрами. Кількість учнів, що відвідувала школи-інтернати коливалась у різних місцевостях від 50 до 400. Наявність в одній школі декількох вчителів і великої кількості учнів у класах унеможливлювала формування позитивних стосунків між дорослими та дітьми, ускладнювала встановлення взаєморозуміння та поваги [3]. 
Навчально-виховний процес у школахінтернатах складався із двох компонентів: навчання в аудиторії та розвиток практичних умінь і навичок. Останній, на думку канадських дослідників, займав набагато більше часу [5]. Розвиток практичних умінь і навичок відбувалось як у формі інструктажу у спеціально відведених майстернях, так i y вигляді виконання повсякденних обов'язків. Хлопчиків заставляли чистити конюшні, доглядати за свійськими тваринами, лагодити різноманітне сільськогосподарське обладнання, працювати в полі, опановувати різноманітні види ремісничої діяльності, серед яких найпопулярнішими були теслярство, ковальство, друкарство та виготовлення взуття. Дівчаток навчали підтримувати чистоту в школі, прати білизну, шити одяг, мити підлогу та виконувати іншу хатню роботу. Така діяльність служила не лише засобом навчання, але й мала значення для підтримки функціонування усієї школи. Діти самі собі шили одяг, прали, готували їсти із плодів сільськогосподарської діяльності. Більшість дітей не проводило навіть половини дня у класі. Навчання у школах-інтернатах в основному зводилось до підготовки дітей до повсякденного життя у християнській родині [5].

На думку Дж. Міллоя (J. Milloy), у школі, яка служила дітям домівкою, найбільше виховне та навчальне значення мали не стільки навчальні програми, скільки стиль життя, у процесі якого одна культура і поведінка були замінені на іншу, кардинально протилежну. Початок шкільного року для найменших школярів супроводжувався обстриганням традиційних локонів довгого волосся, переодяганням в європейський одяг, заміною традиційного взуття на черевики. 3 того часу діти повинні були жити у безвідмовній покорі вчителю та відповідно до чіткого розкладу, де похвилинно було розписано час, що відводився на сон, навчання, молитви, працю, дозвілля. Для дітей, що спокон віків були оточені природою, а їхні сім'ї слідували лише сезонним змінам навколишнього середовища, сама концепція часу і щохвилинної рутини була чи не найбільшим культурним шоком [6].

Змістовий компонент навчально-виховного процесу у школах-інтернатах для освіти дітей корінного населення визначався навчальними програмами, які розроблялись на федеральному рівні Департаментом у справах індіанців і спершу базувались на навчальних програмах загальноосвітніх шкіл провінції Онтаріо. Як відомо, система освіти провінції Онтаріо була однією із перших систем освіти, які динамічно розвивались, а згодом була покладена в основу освітніх систем інших провінцій і територій Канади.

У 1896 р. Департамент у справах індіанців оприлюднив Навчальну програму для індіанських шкіл (англ. Programme of Studies for Indian Schools), яка передбачала опанування англійської мови, загальних знань, письма, арифметики, географії, етики, читання, історії, а також декламації, гімнастики, вокального мистецтва та релігіі.

Головною особливістю навчальних програм було те, що вони були євроцентристськими, тобто пропагували європейські цінності, стиль життя, релігію, соціальні відносини, звичаї і традиції європейського континенту тощо. На думку тогочасних політиків, це сприяло забезпеченню дисципліни і стимулювало процес цивілізування корінного населення. Часто спортивні змагання супроводжувались виконанням патріотичних пісень. До кінця 40-х рр. ХХ ст. час на виконання учнями повсякденних обов'язків у школі та сільськогосподарської діяльності поступово зменшувався, натомість все більше часу виділялось на проведення різноманітних спортивних змагань, занять танцями, участі у музичних гуртках [2].

Висновки. Отже, як свідчать результати виконаного дослідження, з 1620 по 1948 рр. триває період асиміляції в освіті корінних жителів Канади, пов'язаний iз приходом європейських першопоселенців, серед яких освітніми питаннями займались представники релігійних громад (францисканські монахи, єзуїти, монахині ордену св. Урсули). Вони навчали корінних жителів французької та англійської мови, християнської етики, викладали основи ведення сільського господарства. Водночас, представники релігійних громад пропонували європейський підхід до організації навчально-виховної діяльності, заснований на дисципліні, покорі вчителю, заучуванні текстів на пам'ять. Такий підхід не приносив позитивних результатів, оскільки не враховував традицій, притаманних культурі корінних народів. Період асиміляції характеризується відкриттям спеціальних шкілінтернатів для дітей корінних жителів, які повинні були проживати і навчатись у цих школах. Основною метою перебування дітей в таких школах була повна заміна рідної культури корінних жителів на іншу, європейську. Це супроводжувалося жорсткою мовною політикою, викоріненням традицій, застосуванням фізичних покарань тощо. Особливістю освіти цього періоду $\epsilon$ централізація управління освітою федеральним урядом країни. 
Перспективи подальших розвідок. Виконане дослідження не вичерпує усіх аспектів окресленої проблеми. До перспективи подальших розвідок відносимо вивчення дидактичної системи, що застосовувалася в означений період, а також аналіз політики уряду Канади щодо розвитку освіти корінних народів в наступні століття.

\section{ЛІТЕРАТУРА}

1. Davinm, N. (1879). Report on the Industrial Schools for Indians and Half-Breeds. Retrieved from: https://archive.org/details/cihm_03651 [in English].

2. Haig-Brown, C. (1998). Resistance and Renewal: Surviving the Indian Residential School. Arsenal Pulp Press, 172 p. [in English].

3. Hare, J. \& Barman, J. (2000). Aboriginal Education: Is There a Way Ahead? In D. Long, P. Dickason (eds.).
Visions of the Heart: Canadian Aboriginal Issues. Toronto: Hardcourt Canada, pp. 331-359. [in English].

4. Hawthorn, H. (1967). A Survey of the Contemporary Indians of Canada. Ottawa: Indian Affairs Branch. vol. 2, 251 p. [in English].

5. Kirkness, V. (2013). Aboriginal Education in Canada: a Retrosprctive and a Prospective. In F. Widdowson, A. Howard (eds.). Approaches to Aboriginal Education in Canada. Brush Education, pp. 7-26. [in English].

6. Milloy, J. (1999). A National Crime: The Canadian Government and the Residential School System 1789 to 1986. University of Manitoba Press, 402 p. [in English].

7. White, J. \& Peters, J. (2013). A Short History of Aboriginal Education in Canada. Aboriginal Education: Current Crisis and Future Alternatives. Thompson Educational Publishing, 2013, pp. 13-31. [in English].

Стаття надійшла до редакції 27.02.2018

УДК 378.147.091.33-027.22:378.22

DOI:

Сергій Ящук, доктор педагогічних наук, професор, доцент кафедри техніко-технологічних дисциплін, охорони праці та безпеки життєдіяльності

Уманського державного педагогічного університету імені Павла Тичини

\section{КОНЦЕПТУАЛЬНІ ОСНОВИ ПРОФЕСІЙНОЇ ПІДГОТОВКИ МАЙБУТНІХ ВИКЛАДАЧІВ ЗАГАЛЬНОТЕХНІЧНИХ ДИСЦИПЛІН ТА МЕТОДИКИ НАВЧАННЯ ТЕХНОЛОГЙ}

У статті обтрунтовуються концептуальні основи професійної підготовки майбутніх магістрів технологічної освіти у вищих педагогічних навчальних закладах України. Розкрито теоретичні підходи до розробки конщепџї професійної підготовки магістра технологічної освіти, які відображають науково обтрунтовану побудову структуру змісту техніко-технологічної та методичної системи; визначено основні напрями ї̈ вдосконалення 6 контексті забезпечення якісної традищійної підготовки майбутнього фахівия для вищої педагогічної иколи.

Ключові слова: концепчія; професійна підготовка; технологічна освіта; магістр; викладач.

Jim. 5.

Serhiy Yashchuk, Doctor of Sciences (Pedagogy), Professor, Associate Professor of the TechnoTechnological Disciplines, Labor Protection and Safety of Life Department Uman Pavlo Tychyna State Pedagogical University

\section{THE CONCEPTUALFOUNDATIONSOF PROFESSIONALTRAINING OF MASTERS OFTHETECHNOLOGICAL EDUCATIONINTHE HIGHER PEDAGOGICALEDUCATIONALINSTITUTIONSOFUKRAINE}

The conceptual foundations of educational training of future Masters of technology in the Ukrainian higher educational establishments have been grounded in the article. The basic components of the training, the concepts: a future teacher of general technical subjects, and methods of teaching of technology have been analyzed, they are as follows: training content should be considered from the standpoint of competency approach; training should be based as an integrative unity of educational programs and individual characteristics, the professional interests and intentions of students; the educational process of Masters will take a high quality if during the selection of training content to adhere to the certain principles and systems to create the necessary conditions for the implementation of this content; the qualitative training of future Masters is not possible without an optimal combination of theory and practice.

The theoretical approaches to the development of the concept of Master of technological education training that reflect the scientifically based content structuring of technical and technological and methodological system, the main directions of its improvement in the context of traditional training of future specialist for a higher pedagogical school have been determined.

Keywords: a concept; training; technology education; a Master; a teacher.

П остановка проблеми. Зміни освітньої парадигми в Україні спрямовані на модернізацію вищої школи та підготовку майбутніх фахівців високої кваліфікації, які можуть конкурувати на ринку праці. Сучасна державна політика у сфері освіти
(C) С. Ящук, 2018 